\title{
Увођење услуга за особе са оштећеним видом - искуства Универзитетске библиотеке „Никола Тесла" у Нишу
}

\author{
Снежана Јанчић \\ Универзитет у Нишу \\ Универзитетска библиотека „Никола Тесла“, Ниш \\ snezana.jancic@ni.ac.rs
}

\section{Сажетак}

Пружање услуга особама са инвалидитетом представља важан сегмент рада у библиотекама. У тексту је описан процес увођења сервиса за кориснике са оштећеним видом у Универзитетској библиотеци „Никола Тесла“ у Нишу. Укључивањем у TEMPUS пројекат Једнак приступ за све: оснаживање социјалне димензије у циљу јачања Европског простора високог образовања 2013. године и добијањем асистивне опреме за слепе и слабовиде студенте Универзитета у Нишу, Библиотека почиње да се на организован начин бави њиховим потребама и за њих развија специјализоване услуге. Анализом начина на које се овој категорији корисника могу побољшати услови студирања, упознавањем са правном регулативом, пре свега, у области библиотекарства и заштите ауторских права, успостављањем сарадње са институцијама које такве услуге већ пружају, обуком запослених и израдом упутстава, створене су основе за почетак рада. Од тада су сервиси за слепе и слабовиде, од којих је најзначајније прилагођавање литературе у њима приступачним форматима, постале део стандардних библиотечких услуга.

Кључне речи: особе са оштећеним видом, специјализоване библиотечко-информационе услуге, асистивне технологије, литература прилагођена слепим и слабовидим особама, приступачни формати, Универзитетска библиотека „Никола Тесла“, Ниш

Увод

Једна од кључних улога библиотека широм света је да свим својим корисницима обезбеде приступ потребним информацијама, под једнаким условима. Њихови ресурси и услуге намењени су задовољавању образовних и културних потреба свих групација корисника, укључујући и оне с инвалидитетом. Ове особе се у свакодневном животу суочавају с различитим ограничењима, па библиотеке, као центри знања у дигиталном добу, морају бити предводници у рушењу тих баријера, тако што ће им изворе информација, сервисе и простор учинити доступним. ${ }^{1}$

Особе са оштећеним видом могу користити литературу само у њима прилагођеним облицима, што им је умногоме ограничавало приступ информацијама. Са развојем савремених информационих технологија, та ситуација се поправља, па они почињу да претражују интернет, онлајн библиотечке каталоге и базе података и користе електронску пошту, а појавом дигиталних формата, литература им постаје много доступнија. Тако они данас, поред текстова на Брајевом писму, оних у облику аудио књига или са увеличаним принтом, имају и могућност самосталног коришћења електронских публикација, уз помоћ рачунара и говорних софтвера који читају текст са екрана. ${ }^{2}$

\footnotetext{
1 Junaid Rayini, "Library and information services to the visually impaired persons", Library Philosophy and Practice (e-journal) (June 2017), preuzeto 14. 2. 2019, https://digitalcommons.unl.edu/libphilprac/1510/.

2 Koraljka Golub, "Digital libraries and the blind and visually impaired" (Conference paper presented in 4th CARNet Users Conference-CUC, Zagreb, Croatia, 25-27 September 2002), preuzeto 25. 1. 2019, http://eprints.rclis.org/4391/.
} 
У нашој земљи, највећи део уџбеничке литературе за основне школе штампан је на Брајевом писму или је прилагођен у другим форматима (.pdf, .doc, .mp3, .wav...). Међутим, за средње и високо образовање нема адаптираних уџбеника, па се, након завршене средње школе, због недостатка подршке, невелики број ових особа одлучује на студирање.

Универзитетска библиотека у Нишу је међу својим корисницима и раније имала оне с оштећеним видом, али је могла да им понуди само стандардне услуге. Тек када је 2013. године укључена у међународни TEMPUS пројекат Јеgнак ирисйуй за све: оснаживање социјалне gимензије у ииљу јачања Евройскої иросйора високої образовања (2012-2015), добила је прилику да за ове студенте организује специјализоване сервисе.

\section{Пројекат Једнак приступ за све}

Главни циљ пројекта био је побољшање положаја мање заступљених социјалних група у оквиру високог образовања, као што су студенти са инвалидитетом, лошијег материјалног стања, или ромске националности, како би они на тржишту рада имали подједнаке шансе као и сви остали. Његов руководилац био је Универзитет у Нишу, а реализовала су га четири универзитета из Европске уније и пет из Србије, у партнерству са три студентска удружења и Републичким заводом за статистику и уз подршку Министарства просвете и науке Републике Србије. Једна од институција-учесника у пројекту, била је и Универзитетска библиотека.

Пројектом је било предвиђено увођење асистивних технологија ${ }^{4}$ за студенте с инвалидитетом. Поред подесивог намештаја за кориснике у инвалидским колицима, највећи део асистивне опреме коју је Библиотека добила, чинила је она за особе са оштећеним видом: Брајев штампач, електронска лупа, рачунари и одговарајући софтвери: JAWS стандард софтвер - читач екрана, синтетизатор говора AnReader - намењен читању српских ћириличних и латиничних текстова и Abby Fine Reader 11 Professional Edition - софтвер за претварање штампаног текста у текст датотеку.

Уз учешће Центра за подршку студентима Универзитета у Нишу и у сарадњи са Нишким удружењем студената с хендикепом, ступило се у контакт са слепим и слабовидим студентима, у то време њих десетак (највише са факултета друштвених и хуманистичких наука, ниједан са природних и техничких). Они су Библиотеци пружили драгоцену помоћ приликом инсталације асистивне опреме и одговарајућих софтвера. На серији састанака сагледане су њихове потребе и установљени начини на које им Библиотека може помоћи. Иако су они високо оспособљени да своје потребе за знањем задовољавају самостално, и даље су им потребне услуге штампања материјала на Брајевом писму и претварања штампаних текстова у електронске. Међутим, само дигитализовање текстова није довољно: оно што им заиста олакшава употребу литературе и чини је потпуно доступном, јесте заправо њено додатно прилагођавање.

\section{Законски оквир}

Основа за стицање неопходних знања из ове области била су документа IFLA Секције библиотека за особе с тешкоћама у читању штампаног материјала (Libraries Serving Persons with Print Disabilities Section) и њихове Смернице за развој библиотека за слепе у ннформатичком добу. ${ }^{5}$ Оне се темеље на постулатима Конвенције Уједињених нација о правима особа с

\footnotetext{
3 University of Niš, Equal Access for All: Strengthening the Social Dimension for a Stronger European Higher Education Area (Equied), preuzeto 25. 1. 2019, http://www.equied.ni.ac.rs/.

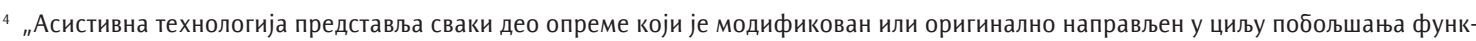

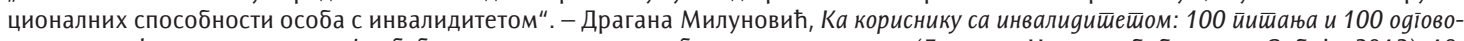
ра у вези са формирањем и развојем библиоетеиких услуїа за особе са инвалиgишеиеом (Београд: Народна библиотека Србије, 2012$), 18$.

5 IFLA Libraries Serving Persons with Print Disabilities Section, "Libraries for the Blind in the Information Age - Guidelines for Development", preuzeto 25. 1. 2019. https://www.ifla.org/publications/ifla-professional-reports-86?og=72.
} 
ивалидитетом, ${ }^{6}$ коју је Република Србија ратификовала 2009. године. У њеном члану 21. (а) о слободи изражавања и мишљења и приступу информацијама, наводи се обавеза да се овим особама „пруже информације које су намењене широј јавности, у приступачним форматима и технологијама одговарајућим за различите врсте инвалидитета, благовремено и без додатних трошкова“. Полазећи од ове обавезе, као и од чињенице да је особама с оштећеним видом у потпуности доступно само пет (у најразвијенијим земљама седам) посто информација објављених у свету, од велике је важности за сваку библиотеку да за ову категорију корисника развије ефикасне услуге, формира колекцију у алтернативним форматима и учини им је доступном.

На глобалом нивоу, један од најзначајнијих докумената је Споразум из Маракеша (Мароко $)^{7}$ из 2013. године, који је, у сарадњи са Светском унијом слепих особа (World Blind Union) и библиотечким асоцијацијама, усвојила Светска организација за интелектуалну својину (WIPO - World Intellectual Property Organization). Њиме је установљен стандардни сет ограничења и изузетака у оквиру Закона о ауторским и сродним правима, што је свима који имају потешкоће у читању значајно олакшало приступ објављеним публикацијама: омогућена је њихова производња у прилагођеним форматима, умножавање и дистрибуција, као и међународна размена. Наша земља још увек није ратификовала овај споразум, али је у плану да се то учини.

Од домаћих закона, у Закону о библиотечко-информационој делатности, у сегменту о правима корисника библиотеке, наводи се: „Свака библиотека дужна је да обезбеди услове за остваривање права корисника библиотеке, укључујући и посебне корисничке групе, као и кориснике са инвалидитетом“. ${ }^{8}$

С обзиром на то да скенирање, претварање слика у текст, прилагођавање и достављање материјала представља „умножавање и дистрибуцију“ туђег ауторског дела, што је, према Закону о ауторским и сродним правима, могуће само уз дозволу носиоца ауторских права, за обезбеђивање приступа информацијама особама са оштећеим видом направљен је изузетак, па је библиотекама дозвољено прављење модификованих копија дела”: „За потребе особа са инвалидитетом, дозвољено је без дозволе аутора и без плаћања ауторске накнаде, умножавање и стављање у промет ауторског дела, ако то дело не постоји у траженом облику, ако је његова употреба у директној вези са инвалидитетом тих особа и у обиму који захтева одређена врста инвалидитета и ако то умножавање и стављање у промет није учињено ради остваривања посредне или непосредне имовинске користи". ${ }^{10}$

У Закону о уџбеницима је такође предвиђено да „ученици са инвалидитетом користе уџбенике чији је формат, односно писмо, прилагођено њиховим потребама“. ${ }^{11}$

\section{Практичан рад}

По процени IFLA-е, можда највећу препреку пружању библиотечких услуга корисницима с оштећеним видом, представља недостатак обуке и одговарајућих вештина запослених. ${ }^{12}$ У том циљу, пројектни тим је посетио библиотеке специјализоване за рад са овим особама, као што су

\footnotetext{
6 Генерална скупштина Уједињених нација, „Конвенција о правима особа с инвалидитетом“, Канцеларија за људска и мањинска права, преузето 22. 1. 2019, http://www.ljudskaprava.gov.rs/sr/node/155.

WIPO, "Marrakesh Treaty to Facilitate Access to Published Works for Persons Who Are Blind, Visually Impaired, or Otherwise Print Disabled (MVT)", preuzeto 25. 1. 2019, https://www.wipo.int/treaties/en/ip/marrakesh/.

8 "Zakon o bibliotečkoinformacionoj delatnosti“, Službeni glasnik RS broj 52 (2011), član 29., preuzeto 22. 1. 2019, https://www. nb.rs/pages/article.php?id=1453.

9 Stela Filipi Matutinović, prir., Autorska prava za bibliotekare (Beograd: Univerzitetska biblioteka "Svetozar Marković" , 2013), 70.

10 "Zakon o autorskim i srodnim pravima“, Službeni glasnik RS broj 104/2009, 99/2011, 119/2012 i 29/2016 - odluka US, član 54., preuzeto 22. 1. 2019, https://www.paragraf.rs/propisi/zakon_o_autorskom_i_srodnim_pravima.html.

11 "Zakon o udžbenicima", Službeni glasnik RS broj 68/2015, član 4., preuzeto 22. 1. 2019, http://demo.paragraf.rs/ WebParagrafDemo/?did=282497.

12 Dragana Milunović, Biblioteke za hendikepirane (Beograd: Zadužbina Andrejević, 2006), 19.
} 
Центар за слепе и слабовиде Народне библиотеке Србије и Библиотека Савеза слепих Србије „Др Милан Будимир“ у Београду, од којих су добијене конкретне смернице за рад, а договорена је и међусобна размена прилагођеног материјала. Додатна знања библиотекари су стекли на предавањима и радионицама Удружења за подршку инклузији мањинских група „Инклузивна мрежа“.

Пред сам почетак активности, урађена су упутства којима се дефинишу пружање нових услуга и процес прилагођавања текстова.

„Упутство за пружање услуга слепим и слабовидим особама“13 утврђује услове и начине пружања библиотечких услуга овој категорији корисника, као и њихове и обавезе Библиотеке приликом коришћења специфичне библиотечко-информационе грађе, извора и сервиса, у складу са Законом о ауторским и сродним правима. Поред стандардних, Библиотека пружа и следеће посебне услуге: скенирање штампаних текстова и њихово прилагођавање за читање помоћу синтетизатора говора, уређивање текстова на Брајевом писму, као и њихово штампање. Обавезе судената су да, приликом коришћења прилагођеног материјала, поштују ауторска права, тј. да се придржавају одредби Закона и Правилника Библиотеке. То подразумева да добијене текстове студенти могу користити искључиво за сопствене образовне, научне или културне потребе, да њихова комерцијална употреба није дозвољена, као и да се они не смеју умножавати, уступати другим особама или стављати у јавни домен. Пре добијања првог прилагођеног текста, корисници потписују изјаву којом се обавезују да ће ове одредбе поштовати.

„Упутство за дигитализовање и прилагођавање текстова за слепе и слабовиде особе ${ }^{\prime 14}$ урађено је у сарадњи са студентима, на основу искустава у пробном раду са електронским текстовима и у складу с препорукама консултованих библиотека. Циљ Упутства је да се непосредним извршиоцима стандардизује процес рада, детаљним описом свих његових сегмената, како би се студентима омогућило потпуно разумевање прилагођеног текста и његово што ефикасније коришћење. Њиме се дефинишу принципи избора текстова за дигитализацију и прилагођавање, дају се смернице за њихову техничку обраду и прописује начин заштите и чувања грађе.

Избор текстова врши се према приоритетима, на основу утврђених потреба студената за литературом у тој школској години.

Требало би напоменути да говорни софтвери не могу подједнако успешно да препознају и читају све електронске формате и да је за особе оштећеног вида најпогодније коришћење фајлова у Microsoft Office Word .doc и .docx форматима. ${ }^{15}$ Стога је штампане текстове потребно прво скенирати (сваку страницу посебно, у датотеку типа .bmp или .jpg), а онда скениране слике текста, програмом OCR (Optical character recognition), претворити у дигитализовани текст .doc или .docx типа. Он се затим упоређује са оригиналним и коригује и, након добијања исправљене електронске верзије, додатно прилагођава потребама слепих и слабовидих корисника (на посебан начин се нпр. обрађују табеле, слике и референце, врши подела текста и обележавају датотеке). Обрађени текстови достављају се корисницима на њима одговарујући начин.

Због заштите ауторских права, са прилагођеним текстовима поступа се посебно опрезно. Библиотека ове датотеке архивира у локалну базу података, евидентира и трајно чува.

Након обављених припрема, почела је имплементација нових сервиса. До сада је за слепе и слабовиде студенте дигитализовано и прилагођено више десетина уџбеника и одштампано на стотине страница материјала на Брајевом писму. Брајев штампач такође повремено користи и Савез слепих Ниша, као и остали грађани са овим потребама.

13 Универзитетска библиотека „Никола Тесла“, Ниш, „Упутство за пружање услуга слепим и слабовидим особама“, преузето 21. 1. 2019, http://www.ubnt.ni.ac.rs/index.php/component/content/article?layout=edit\&id=210.

14 Архива Универзитетске библиотеке „Никола Тесла“, Ниш, „Упутство за дигитализовање и прилагођавање текстова за слепе и слабовиде особе" (бр. 21/1-16-00, интерни документ).

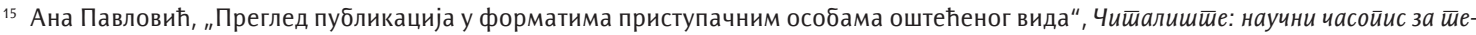
орију и ирраксу библиойекарсиива Година XVII, бр. 32 (мај 2018): 71, doi: 10.19090/cit.2018.32.67-73, преузето 25. 1. 2019, http:// citaliste.rs/casopis/br32/pavlovic_ana1.html. 


\section{Закључак}

Сервиси за особе са оштећеним видом данас су део редовних библиотечких услуга Универзитетске библиотеке „Никола Тесла“ у Нишу. На тај начин, остварен је и један од предвиђених циљева у „Стратегији развоја Универзитетске библиотеке за период 2012-2017.“ - прилагођавање услуга посебним категоријама корисника, односно процес њихове „персонализације“.

Слепи и слабовиди студенти редовни су корисници ових услуга. За разлику од времена пре њиховог увођења, када су само могли да позајме библиотечку грађу и даље се сами сналазе у погледу њеног коришћења, данас се она за њихове потребе скенира и потпуно прилагођава. Циљ Библиотеке је да ове особе охрабри да што већи број стекне високо образовање.

Док се на државном нивоу, са издавачима, системски не реши питање обезбеђивања литературе, пре свега уџбеника за све нивое образовања, у форматима приступачним особама са оштећеним видом, било би пожељно да библиотеке које имају ову врсту услуга, кад год је то могуће, уз штампани, добијају и електронски примерак публикација, како би се време потребно за дигитализцију штампаних текстова уштедело и одмах приступило процесу њиховог прилагођавања.

\section{Литература и извори:}

1. Arhiva Univerzitetske biblioteke "Nikola Tesla“, Niš. „Uputstvo za digitalizovanje i prilagođavanje tekstova za slepe i slabovide osobe". Br. 21/1-16-00. Interni dokument.

2. Filipi Matutinović, Stela, prev. Autorska prava za bibliotekare: priručnik. Beograd: Univerzitetska biblioteka "Svetozar Marković", 2013.

3. Generalna skupština Ujedinjenih nacija. „Konvencija o pravima osoba sa invaliditetom”. Kancelarija za ljudska i manjinska prava. Preuzeto 22. 1. 2019. http://www.ljudskaprava.gov.rs/sr/node/155.

4. Golub, Koraljka. "Digital libraries and the blind and visually impaired". Conference paper presented in 4th CARNet Users Conference-CUC, Zagreb, Croatia, 25-27 September 2002. Preuzeto 25. 1. 2019. http://eprints.rclis.org/4391/.

5. IFLA Libraries Serving Persons with Print Disabilities Section. "Libraries for the Blind in the Information Age - Guidelines for Development". Preuzeto 25. 1. 2019. https://www.ifla.org/publications/ ifla-professional-reports-86?og=72.

6. Milunović, Dragana. Biblioteke za hendikepirane. Beograd: Zadužbina Andrejević, 2006.

7. Milunović, Dragana. Ka korisniku sa invaliditetom: 100 pitanja i 100 odgovora u vezi sa formiranjem i razvojem bibliotečkih usluga za osobe sa invaliditetom. Beograd: Narodna biblioteka Srbije, 2012.

8. Pavlović, Ana. „Pregled publikacija u formatima pristupačnim osobama oštećenog vida“. Čitalište: naučni časopis za teoriju i praksu bibliotekarstva Godina XVII, br. 32 (maj 2018): 67-73. doi: 10.19090/ cit.2018.32.67-73. Preuzeto 25. 1. 2019. http://citaliste.rs/casopis/br32/pavlovic_ana1.html.

9. Rayini, Junaid. "Library and information services to the visually impaired persons". Library Philosophy and Practice (e-journal) (June 2017). Preuzeto 14. 2. 2019. https://digitalcommons.unl.edu/ libphilprac/1510/.

10. University of Niš. Equal Access for All: Strengthening the Social Dimension for a Stronger European Higher Education Area (Equied). Preuzeto 25. 1. 2019. http://www.equied.ni.ac.rs/.

11. Univerzitetska biblioteka „Nikola Tesla“. „Uputstvo za pružanje usluga slepim i slabovidim osobama“. Preuzeto 21. 1. 2019. http://www.ubnt.ni.ac.rs/index.php/component/content/ article?layout=edit\&id $=210$.

12. WIPO. "Marrakesh Treaty to Facilitate Access to Published Works for Persons Who Are Blind, Visually Impaired or Otherwise Print Disabled". Preuzeto 25. 1. 2019. https://www.wipo.int/treaties/en/ip/ marrakesh/. 
13. „Zakon o autorskim i srodnim pravima“. Službeni glasnik RS broj 104 (2009), 99 (2011), 119 (2012) i 29 (2016) - odluka US. Preuzeto 22. 1. 2019. https://www.paragraf.rs/propisi/zakon_o_autorskom_i_srodnim_pravima.html.

14. „Zakon o bibliotečkoinformacionoj delatnosti“. Službeni glasnik RS broj 52 (2011). Preuzeto 22. 1. 2019. https://www.nb.rs/pages/article.php?id=1453.

15. „Zakon o udžbenicima“. Službeni glasnik RS broj 68 (2015). Preuzeto 22. 1. 2019. http://demo.paragraf. rs/WebParagrafDemo/?did=282497.

\title{
Introducing Services for Visually Impaired Persons - Experience of the University Library Nikola Tesla, Niš
}

\begin{abstract}
Summary
Providing library and information services to persons with disabilities has always been an extremely important segment of work in libraries, and it is especially challenging nowadays, in the digital age. This paper describes the process of introducing services for blind and visually impaired users at the University Library Nikola Tesla in Niš, which improves their studying conditions. By joining the TEMPUS project entitled Equal Access for All: Strengthening the Social Dimension for a Stronger European Higher Education Area in 2013, during which the University Library was equipped with the assistive technology for visually impaired students of the Niš University (Braille printer, magnifying glass, computers and corresponding software), it started to deal with the needs of this category of users in an organized manner and developed specialized library and information services to meet their requirements. This goal was reached by analyzing their needs, gaining knowledge in the field of legal regulations such as international and Serbian copyright laws and treaties, establishing cooperation with other institutions with experience in providing such services, composing necessary instruction manuals, and training of the library staff. Since then, the services for blind and visually impaired students, among which the most important one is producing specially-adapted books in accessible formats, which are hosted at the University Library local repository, have become a part of the standard library services.
\end{abstract}

Keywords: visually impaired persons, specialized library and information services, assistive technology, adapted literature for the blind and visually impaired, accessible formats, University Library Nikola Tesla, Niš 


\section{(c) (1) ()}

Увођење услуга за особе са оштећеним видом - искуства Универзитетске библиотеке „Никола Тесла" у Нишу by Снежана Јанчић is licensed under a Creative Commons Attribution-NonCommercial-NoDerivatives 4.0 International License. 